Vol. 1, No. 1, Januari 2020: h. 106-130. DOI: 10.35672/jnus.v1i1.106-130 Website: http://jnus.lakpesdamsalatiga.or.id/index.php/jnus/index

\title{
The Influence of Social Media for The Development of Da'wah And Nahdlatul Ulama Society Behavior
}

\author{
Avin Wimar Budyastomo \\ LAIN Salatiga \\ wimar1984@gmail.com
}

\begin{abstract}
The development of information technology is felt so rapidly. All fields have used information technology; both in medicine and exact science, and even now the religious field has used it. One of the advantages of information technology in the field of religion is the emergence of sites that contain da'wah or religious promotions. This is very different from the time of Prophet Muhammad SAW when delivering da'wah for the first time. He delivered da'wah stealthily and took very long time, but the existence of social media turned into open and transparent media and saved time and energy. In addition, social media can also be used as a media that changes the behavior and lifestyle of society, one of which is the nature of dependence on social media and fashion changes very quickly.
\end{abstract}

Keywords: Social Media; Da'wah; Community Behavior; Nabdtatul Ulama

\section{INTRODUCTION}

The development of information and communication technology has grown very rapidly in the community. Generally, information technology is a technology used to manage data, including processing, obtaining, compiling, storing, and manipulating data with various ways and procedures to produce information quality and high value. The development of information and communication technology continues to increase along with the increase of human needs. With the existence of information and communication technology, it can facilitate us to learn and get information we need from anywhere, anytime, and anyone. 
Among the information technology that almost every place we find is a computer. Now the computer is growing very rapidly. Almost every year the computer develops so fast. People can use the computer anywhere like at home, cafe, school, and elsewhere. While the model and design of the computer itself is also experiencing growth. In the past when people want to use the computer, they can only use it at office or home, but now they can use the computer wherever they want.

The development of information technology increasingly affect human life. Along its development, the people of Indonesia began to recognize the internet, television, radio and others. One of them is Internet which is a form of integration between the flow of communication and the development of technology. One of the most popular web-based services is social networking site. Indonesia became a country in Asia that experiences the second rapid growth after Malaysia in accessing one of the social network (Facebook). The increasing number of social network users in Indonesia is due to the increasingly complete internet access facility by mobile phone producers and communications service providers. Television is electronic mass media most in demand by the public and most have a great influence on the knowledge, motivation, and attitudes of the audience without considering the age, gender, position, and so forth. Compared to other communication media, television can exert a stronger influence than radio and newspaper. This happens because of the power of visual audio of television that touches the psychological aspects of viewers. The pattern of social media used by adolescents can be influenced by the family, environment, and characteristics of individual adolescent. The 
Vol. 1, No. 1, Januari 2020: h. 106-130. DOI: 10.35672/jnus.v1i1.106-130

Website: http://jnus.lakpesdamsalatiga.or.id/index.php/jnus/index

family is the first and foremost environment that gives much influence to various aspects of children's social development. Teenagers or children who have middle to upper economic background can easily access network or other social media using Mobile or internet facility at home or internet cafes. Many of the benefits generated by the use of social media, such as a means of message delivery, discussion among social media users, economical, accurate, easy and comfortable to manage.

\section{METHODOLOGY}

The development of social media will bring a great influence on the development of da'wah and behavior of Nahdlatul Ulama Society. The focus of this issue can be described as follows: How social media influence the development of da'wah and behavior of people in Indonesia. What is the influence of social media on the development of da'wah and mass media in Indonesia.

Social media is an online media. Online users can easily participate, share, and create content of the media. The media includes blogs, social networks, wikis, forums, and virtual worlds. From those examples, blogs, social networks and wikis are the most common form of social media used by people around the world.

According to Andreas Kaplan and Michael Haenlein the definition of social media is "an internet-based application group that builds the foundation of Web 2.0 ideology and technology, and which enables the creation and exchange of user-generated content". Social media is a media used by individuals being to be social, being or 
becoming social online by sharing content, news, photos and others with others (Varinder Taprial and Priya Kanwar, 2012).

According to Michael Cross (2013), Social media is a term that describes the various technologies used to tie people into collaboration, exchange of information, and to interact through web-based messaging. Because internet is always growing and develops so fast, the various technologies and features, that is available to users, are always changing. This makes social media more hypernym than a specific reference to various use or design. Social media is a great place to meet and connect with friends or new acquaintances. Almost every day, millions of users connect their accounts to social media with various intents and purposes. Some use social media for business or just socializing. Features that are presented on a social media is very influential in the number of users. So the founders of social media often add and continue to improve the features that have to be different from others. Some examples of the features are as follows: videocall on Whatsapp, Twitter's mute feature (mute feature to disable unwanted tweets), Boomerang (an app that works to display photos with duration of 2 - 4 seconds will be a video and can be displayed in repetitive and tags on Instagram Stories, sheep feature on path (Users who install Go to sleep status can now get as many sheep as possible, from people who see the post), world lenses feature (add effects to the environment around us when shooting), modern features, social media is also classified in several types: 1). Social Media for Everyday Updates and twitter is famous for its features that can only write 140 characters at once post. The use of twitter is to deliver important short messages. Some social media integrate their app with 
JNUS:Journal of Nahdlatul Ulama Studies

Vol. 1, No. 1, Januari 2020: h. 106-130. DOI: 10.35672/jnus.v1i1.106-130

Website: http://jnus.lakpesdamsalatiga.or.id/index.php/jnus/index

twitter, so we can post content in other social media to twitter. The use of facebook, you can add photos, videos, and messages with more character limit than twitter. Anyone who wants to add your account as a friend, must go through the approval process first. Facebook is also integrated with many other social media. 2). Social Media for Photos. Flickr application is a perfect media for sharing professional photos you take. Through flickr, we can download and upload high resolution photos. Flickr is usually used by photographers to build their portfolios. With Instagram application you can use for photography enthusiasts though you are not very skilful. Through instagram, users can edit their photos with the features that have been provided by instagram. Photographers sometimes use instagram as their portfolio container. Snapchat is an app that works to share selfie, video, or other photos. Snapchat also has filters and effects that are guaranteed to make users addicted to use snapchats. 3). Social media for sharing science and hobbies. Media is like twitter, but has been developed with more features. So the media is more properly referred as blog. Media is usually used by professionals to share their knowledge in the form of articles. Media can be used as a place of learning and sharing knowledge for free. Quora application is a forum, where users can ask questions and their questions will be answered by other users. Through quora, you can ask and discuss about various things. You can discuss about hobbies like reading, watching, and sharing knowledge. 


\section{DISCUSSION}

Da'wah (Arabic: دعوة, da'wah; "solicitation") is a calling activity, invites and calls people to believe and obey Allah according to aqidah, shari'ah and morals of Islam. Da'wah in harfiyah means invitation or call, that is the call to go to way of God (Allah SWT). The origin of the word da'wah is da'a yad'u da'wah which means to invite or call.

Da'wah in the sense of amar ma'ruf nabi munkar is absolute requirement for perfection and salvation of people's lives. This is the duty of men who possess the nature as a social being and the obligation affirmed. Therefore, da'wah is not a monopoly of "ulama" or "intellectual people".

Da'wah is synonymous with teaching or kbutbah in the narrow sense. Etymologically, da'wah is derived from Arabic which means the invitation in accordance with Al Qur'an surah Yunus verse 25. Widely, Islamic propaganda is a human effort of faith to influence and invite humankind in a wise way to follow the teaching of Islam in All aspects of life for their benefit and happiness in the world and here after.

In technical term, da'wah means invitation to understand, believe, and practice the teachings of Islam, also invites to goodness and prevent munkar (amar ma'ruf nahyi munkar).

The following $\mathrm{Al}$ Qur'an is the mean of da'wah as an invitation to the way of Allah SWT (Shari'a of Islam), invitation to goodness, and to prevent bad deed or practice. "Call unto the way of thy Lord with wisdom and fair exhortation, and reason with them in the better way. Lo! thy Lord is Best Aware of him who strayeth from His way, and He is Best Aware of those who go aright". (QS. An-Nahl: 125). 
JNUS:Journal of Nahdlatul Ulama Studies

Vol. 1, No. 1, Januari 2020: h. 106-130. DOI: 10.35672/jnus.v1i1.106-130

Website: http://jnus.lakpesdamsalatiga.or.id/index.php/jnus/index

"And who is better in speech than him who prayeth unto his Lord and doeth right, and saith: Lo! I am of those who are muslims (surrender unto Him)?". (QS Fushshilat: 33).

" And there may spring from you a nation who invite to goodness, and enjoin right conduct and forbid indecency. Such are they who are successful". (QS. Ali Imran: 104).

"And let them not divert thee from the revelations of Allah after they have been sent down unto thee; but call (mankind) unto thy Lord, and be not of those who ascribe partners (unto Him)". (QS. Al Qasshash: 87).

"Ye are the best community that hath been raised up for mankind. Ye enjoin right conduct and forbid indecency; and ye believe in Allah. And if the People of the Scripture had believed it had been better for them. Some of them are believers; but most of them are evil-livers". (QS. Ali Imran: 110).

"O Messenger! Make known that which hath been revealed unto thee from thy Lord, for if thou do it not, thou wilt not have conveyed His message. Allah will protect thee from mankind. Lo! Allah guideth not the disbelieving folk”. (Q.S. Al-Maidah 67).

Method of da'wah is also illustrated above verse, that is in QS. An-Nahl: 125, ie with (1) wisdom, (2) good lessons, and (3) good discussion or good argument. From this verse then the scholars provide interpretation and development of da'wah method as follows:

Da'wah Fardiyah, it is kind of da'wah which is carried out by the Muslim personality in term of interpersonal communication, one person to another person or someone to several people in small and limited 
numbers. Da'wah Faradiya usually occurs without preparation. In this category of da'wah, it is including advising co-workers, reprimands, prayers, preventing friends from doing bad, providing an understanding of Islam to someone else, etc.

Da'wah Ammah, it is a common method of da'wah which is done by a missionary, ustadz, or ulama. This da'wah usually in the form of oral communication (speeches, lectures, tausiyah, sermons) addressed to people.

Da'wah Bil Lisan is the method of inviting through word or oral communication (speaking), such as lectures, sermons, or dialogue.

Da'wah Bil Hal is also called Da'wah Bil Qudwah, that is da'wah method through attitudes, actions, examples, or exemplary. Take an example, to establish prayer as soon as the adzan is heard, to help the poor or needy, to fund the construction of mosque or to assist da'wah activities, to reconcile the hostile person, etc.

Da'wah Bit Tadwin also called da'wah bil qolam and da'wah bil kitabah, that is a method of da'wah through writing, like writing articles, books, writing on blog, status in social media, etc.

Da'wah bil hikmah means da'wah wisely, persuasively, and in accordance with the condition or state of the object of da'wah (mad'u). Da'wah bil Hikmah summarizes all methods of preaching before. Da'wah Bil Hikmah can be understood as da'wah in accordance with the demands of the times, demands of needs, or in accordance with the situation and conditions. 
Vol. 1, No. 1, Januari 2020: h. 106-130. DOI: 10.35672/jnus.v1i1.106-130 Website: http://jnus.lakpesdamsalatiga.or.id/index.php/jnus/index

\section{History of Da'wah}

Before the religion of Islam came down, the community lived in jahiliyah (ignorance). So what happened to the Arab community at that time. The community workship statue, drink liquid or kill their daughters, fight each other, gamble, and so on. Islamic da'wah began to spread in the year $612 \mathrm{AD}$. In the span of 30 years, Islamic da'wah has spread throughout the Arabian Peninsula, Iraq, Persia, Egypt, and Syria.

Before the presence of Islam, the city of Medina only consists of two nations, namely Arab and Jewish. Jews themselves are still divided into three tribes, namely Bani Quraizah, Bani Qainuqa, and Bani Nadir. While the Arab nation consists of indigenous tribes and immigrants. The Arab immigrants are from Yemen. The next tribe is called the tribe of Kharzraj and Aus tribe. This Arab tribe will later become the Ansar who help the Prophet when emigrated to Medina.

In $621 \mathrm{AD}$ as many as 10 people from the tribe of Khazraj and Aus came to Prophet Muhammad SAW at Aqabah. In front of the Prophet Muhammad, the people of Khazraj tribe declared themselves to believe in Allah and His Messenger. When the pilgrimage season, as many as 75 people who came from Medina proposed that the Prophet Muhammad SAW emigrated to the city of Medina. That's when the second Bai'atu Aqabah takes place.

Furthermore, the Muslims emigrated to the city of Medina. Hijra that is done is not necessarily the whole of Muslims. Hijrah is done gradually in several groups of entourage. While Prophet Muhammad SAW emigrated accompanied by Abu Bakr As-Shidiq.

On the way to Medina, the Prophet Muhammad and Abu Bakr stopped at a place called Quba. At that place the Prophet Muhammad 
and Abu Bakr stayed for a while and established a mosque named Quba mosque. Then the Prophet continued his journey back to Medina on Friday, September 24, 622 AD. Upon arrival in Madinah, the Prophet Muhammad was greeted by the emigrated Muhajirin and also the Ansar.

Prophet Muhammad and his people migrated from Mecca to Medina is a new phase of propagation of the Prophet. Prophet SAW and his followers get bad treatment of the Quraish infidels when in Mecca.

\section{Mosque Establishment}

In the time of Prophet, the mosque was not only used for praying but also for learning, governing the government, even preparing for war strategy. In Medina, he built the first mosque that was the mosque of Nabawi which meant the mosque of the Prophet. The mosque was founded in the month of rabiulawal year 1 Hijriah. It was only then that the Messenger of Allah established the mosques in the city of Madinah such as the Jumu'ah mosque, Quba mosque, Gamamah mosque, Bani Quraizah mosque, salman mosque, Ubay bin Ka'ab mosque, and Ali mosque.

\section{Introducing and Fratifying the Emigrants and the Ansar}

In Madinah, Prophet Muhammad SAW had many friends from the Ansar and Muhajirin. Some friends who were ratified by the Prophet Muhammad among them was Saad bin Mua'z by Ibn Mas'ud, Andurrahman premises Auf bin Sa'd ibn Rabi and others. This is done by the Prophet with the aim of unifying the ukhuwah of the people regardless of the background of place and so forth. Formulate the Act 
JNUS:Journal of Nahdlatul Ulama Studies

Vol. 1, No. 1, Januari 2020: h. 106-130. DOI: 10.35672/jnus.v1i1.106-130

Website: http://jnus.lakpesdamsalatiga.or.id/index.php/jnus/index

Rasulullah Muhammad SAW set the rights and obligations of Ummah by legalizing a law through Law called the Medina Charter. The charter also contains rights and obligations for the people of Madinah who adhered religion outside of Islam. In general charter of Madinah contains: A means of unifying the Ummah particularly for the tribe of Khazraj and Aus. Direct charter implies recognition of the legality of Prophet Muhammad SAW as a community leader and State media. As judge guarantor of freedom of the people, as a media which guarantees freedom of religion and Tolerance, as a means of cultural filtering of the Arab nation.

\section{E-da'wah}

E-da'wah is simply defined as the implementation of da'wah with information technology, especially the Internet. E-da'wah is the use of information technology as an active-creative response that arises from the awareness of the positive side of the information technology developments. E-da'wah became necessary because of the spread of da'wah is conventionally limited by space and time, while the digital da'wah or e-da'wah can be implemented over space and time. The geographic coverage of e-da'wah is wide so that all Internet users can be touched by this type of da'wah. For enthusiasts of cyberspace, da'wah through cyber is very exciting. This is because the facilities provided by the owners of providers and servers are quite creative and innovative. Just a little extra knowledge about computers especially copy-paste you can already have a free blogger. It's just the creation of web design and updating that require seriousness in managing da'wah management 
through the cyber. However we need to be serious and sincere in various fields as we want.

\section{The influence of the Internet on the development of da'wah}

The emergence of information technology has effect on the emergence of a challenge for Islamic da'wah activists in Indonesia to change the pattern of conventional da'wah to da'wah based on information technology or combine. As a result, various Islamic organizations did not miss to create official websites or even social media as a means of delivering da'wah, to answer the challenge.

The development of the world of communication is an inseparable part of the facility like internet, and the internet can not be separated from social networking such as facebook, yahoo messager, twitter, instagram and other social networks. Various facilities are effective alternative to connect individuals with others in order to establish a harmonious relationship. Therefore, social networking is very precise as a means of building Islamic da'wah. This is done to face the thought wars (ghozwul fikr) created by the western world. Islam faces civilization attacks and threatens foreign world.

Nowadays, the method of da'wah is no longer in the form of discussion or open a particular forum. However, da'wah is also done in a more modern way in terms of not only through conversations in discussion forums but also using technology through media such as television, radio, articles to social networking media.

Seeing the condition of society that has been utilizing technological tools, there are also many religious leaders who use social 
JNUS:Journal of Nahdlatul Ulama Studies

Vol. 1, No. 1, Januari 2020: h. 106-130. DOI: 10.35672/jnus.v1i1.106-130

Website: http://jnus.lakpesdamsalatiga.or.id/index.php/jnus/index

media as a tool to broadcast the teachings of Islamic religion, as done by the House of Sheikh Ali Jaber Purwokerto Central Java. They use social media such as facebook, twitter, BlackBerry Messenger to deliver the teachings of Islam.

The impact we feel with the existence of social media is the ease of community in accessing various information. In terms of social media, da'wah is very useful in the dissemination of information. People in Indonesia are now increasingly using social media.

In addition to examples of social media convenience above, the benefits derived from social media on da'wah media are as follows: Da'wah through the internet, especially social networking can penetrate the boundaries of space and time with the cost and energy is relatively affordable, Internet service users, especially social networks. Every year it increases drastically, can be accessed anywhere and anytime, can reach out to various circles, especially teenagers who don't like religious activities, da'wah through the internet has become one of the people's choices. Their sites are free to choose the material of their preaching, so that computation of the will can be avoided, and the varied mode of delivery has made the Islamic da'wah via the internet especially social networks to reach a wide segment.

Another thing that supports the emergence of da'wah through social media is because there are lots of people who are still innocent about the knowledge of religion. This encouraged the scholars to take the initiative to do da'wah through social media with the aim of inviting the community to utilize the internet as a means to increase knowledge. 
The Influence of Social Media for .... (Avin Wimar Budyastomo)

The emergence of social media is useful especially for the preachers. One of the factors that encourage the da'wah through social media is because of the easy access of internet. The spread of Islamic teaching is fast, broad, interesting and effective.

The number of internet users in Indonesia is also emergence factor of da'wah through social media. The existence of social media has now become a necessity of life for internet users. The presence of the internet makes people more secular than spiritual activity. Therefore, da'wah comes to the community through media that is now widely consumed by public social media.

Da'wah conducted through social media has many advantages for the preachers. In addition to preachers, advantages can also be felt by social media users. They can access freely without time and place restrictions.

Therefore, utilizing social media should be wise and skillful. Using social media wisely will make it easier for someone to learn, find work, send tasks, seek information, shop, or preach. The development of social media is used in various forms of activities, such as education, business, even for da'wah. For example, today we see people use social media like facebook and twitter.

On the other hand, social media also has a negative impact for internet users. One of the examplea is that social media can be easily imitated and misused by irresponsible people who are contrary to the teachings of the da'wah. Then da'wah through social media can also cause misinterpretation. The acquired understanding is likely different from the delivery of the intended message. 
Vol. 1, No. 1, Januari 2020: h. 106-130. DOI: 10.35672/jnus.v1i1.106-130

Website: http://jnus.lakpesdamsalatiga.or.id/index.php/jnus/index

It is also inseparable from the role of media that is only a oneway communication. So if this develops continuously, it can eliminate the meaning of the real teachings. The existence of interaction in da'wah becomes an important thing for the preachers and community itself. Da'wah is more interactive and efficient in delivering da'wah messages.

Utilization of social media as a medium of da'wah is very effective because it is supported by its unlimited nature of space and time. Islamic material and da'wah can be disseminated quickly and efficiently. It becomes very cheap. Information disseminated through social media can reach anyone as long as they can access the internet. Muslims can use the technology for the benefit of Islamic business, hospitality and others. Therefore, Muslims should be able to master and take full advantage of technological developments.

Essentially, the method and means to deliver da'wah are so wide, and it is unlimited. It is because everything that can be done by man and everything which is on this earth are not contrary to Islamic doctrine, and then it can be used as a method and means of da'wah. However, there are some deficiencies when da'wah through social media such as the target is limited to internet users only. Nevertheless da'wah through social media has a very wide scope until the international level.

\section{The Influence of Social Media toward Nahdlatul Ulama Society Behavior}

Social media brings not only positive impact but also good influence on life of people in Indonesia. Indonesian society is not separated from the name of social media. Day by day millions of 
Indonesian people access social media for work purposes, updating news, or just a hobby.

There are some reasons why someone makes an account on social media. Some of them try to stay connected with family and friends, to get information and news through news feeds provided by social media, to show the self existence.

The rise and booming of social media users among teenagers, lately began to emerge the more active assumption of a teenager in social media. They are increasingly considered cool and slang. For teenagers who do not have accounts in social media, they are considered ancient and lack of knowledge of technology. This is a very serious problem. It is because teenagers are still emotional and unstable, thus in daily life, teenagers often use social media for fun and continue to make an image of themselves. In achieving the objects, young people seek to develop behaviors that support their "role" in social media.

Social media is even able to change people to be more consumptive. In order to be considered cool and modern, many young people are encouraged to buy a smartphone that they can use to access social media.

Beside the negative impact, the use of social media has also a very positive impact, especially in the form of interaction socially, politically and economically. The use of social media makes users easy to communicate with friends or family which is possible to meet face to face because of distance factor.

Through internet we can send the required information easily and quickly, as well as in accessing the required information. We can 
Vol. 1, No. 1, Januari 2020: h. 106-130. DOI: 10.35672/jnus.v1i1.106-130

Website: http://jnus.lakpesdamsalatiga.or.id/index.php/jnus/index

meet many friends or family that we have rarely met. Through social media, i.e facebook, we can keep in touch. Social media can be used as a means to share photo, data and other documents. Social media can also be used as a means of promotion with various products and services that can be offered to the social media users without having to spend a large amount of money, but with multiple benefits. Thus, it is not surprising if nowadays you are very easy to find online business through Social media. Even in big cities, the use of political communication through social media becomes a powerful impact to get the candidate pair.

Technically, social media also requires us to change our lifestyles to be more intelligent and able to use the latest technologies, so that we can catch up on technologies from other countries. Today's society is accustomed to working faster. Thus, information is obtained faster and easier. In addition, the features provided by social media today are very helpful.

Positive impacts felt in the use of social media are as follows: 1) Expanding networking; Because of social media sites, teenagers become more easily get friends with others around the world. Although most of them have never met directly. Teenagers will be motivated to learn to develop themselves through friends that they meet online, because they interact and receive feedback from each other. 2) Making it easy to get information. Teenagers become easy to obtain information on the internet because of the blog or website. Besides, social media can also be used as an information field for education, culture, and others. Social networking sites make children and teenagers more friendly, careful and empathetic. For example, teenagers will pay attention when they have a 
friend's birthday. They will also leave comment on their friends' photos, videos and status. Teenagers can maintain friendly relationships even though they can not meet physically. For those reasons, social media make it easy for teenagers to share everything that they want. With the blog, teenagers can easily share life experiences and other things on blog. Blog also can be used as advertising place for teenagers who have online business. Currently, social media has provided advertising services. Social media like blog, facebook, twitter and others may have place for advertisement on the site. By knowing science and technology, we can directly master the use of technologies and can increase knowledge by reading and opening links related to science.

Additionally, the use of social media can also have a negative impact on the community, as we see now that social media is used as a media to bully others by uploading words or images that are unethical, especially those who have important positions both in government and state institutions. Social media is used as a means to revile and even spoil other people. This behavior is very harmful especially concerning the survival of the state of the Republic of Indonesia. Probably in the future, before negative effect of social media develops, we have to control management of the utilization on social media as a means of communication in order to prevent bad things. The use of social media also affects the relationship between husband and wife, because it can trigger jealousy between them if one of them builds relationship with other. There are so many cases about couple that divorce due to the use of social media which is uncontrolled, and when it happens the one who takes the risks of it is innocent children. 
Vol. 1, No. 1, Januari 2020: h. 106-130. DOI: 10.35672/jnus.v1i1.106-130

Website: http://jnus.lakpesdamsalatiga.or.id/index.php/jnus/index

Negative impacts of using social media for teenagers is that it can make them addicted to using social networking without knowing the time. When teenagers use social networking, they take hours without being aware. Teenagers become lazy to communicate with others in the real world. It means the level of understanding of language becomes better, if teenagers are too much communicate in the cyberspace, social networking sites will make teenagers more selfish. They become unaware of the environment around them, it is because most of them spend more time on the internet. The result is they will be less empathetic in real world. It also makes teenagers becomes lazy to learn because they often use social networking to play games on the site. It is because Facebook provides game services that make them addicted to the game. This game causes the lack of courtesy of teenagers today. With social media, it makes teenagers use inappropriate language, and for teenagers who are still innocent, it would be assumed that the language which is used in the game is the modern language of today's children. There are no spelling and grammatical rules on social networking sites, this makes teenagers extremely difficult to distinguish between communicating on social networking sites and in the real world.

\section{Social Media and Behavioral Changes}

The use of social media also brings behavioral changes to society. For example, we have rarely communicated with the surrounding environment, such as when staying in line at service counter, each of them are busy with their smartphone regardless of the people around them, even many people we see, including our co-workers, can not 
complete their work. Because they are busy on commenting or giving comments in facebook or other social media, which is actually not very useful for them.

The impact of social media on our teenagers' behavior is that they become apathetic and indifferent to the environment, we as parents get difficulty to communicate with our children. Let them complete their homework alone. Social media makes our children lazy to learn and difficult to manage. They spend all the time to get information from social media at school or they use social media after school and at home. Children prefer social media to talk about everything instead of their parents and the most dangerous of all is the issues that they convey to social media, the things that they convey including things that are private so that everyone knows. They do not realize that what we are saying has become public consumption and is difficult to recall it. This issue can not be tolerated, we need a solution concerning our children because they are our hope that will continue the leadership in the future.

Without someone's consideration, a lot of people regard that social network shows a picture of their life as a whole. This is wrong, because everyone on social networks will share their best moments in real life. Therefore, there are many things in their hidden lives. Unfortunately, the image can make someone compare their life with others which later can lead to depression.

Actually depression due to social networking is a serious mental health problem. But unfortunately until now the depression caused by social networking has not been recognized as a problem or mental disorder. Although depression due to social networking has not been 
Vol. 1, No. 1, Januari 2020: h. 106-130. DOI: 10.35672/jnus.v1i1.106-130

Website: http://jnus.lakpesdamsalatiga.or.id/index.php/jnus/index

recognized and recorded as one of the problems of mental disorders, the depression is real and can happen to anyone, especially the younger generation who is very familiar with the use of social networking.

Research reveals that the impact of social networks and the internet are very serious. It has impact on men, women, adults, teenagers, and children. This is of course also influenced by the tendency of a person to experience depression, so it can be varied on every person. But research also shows that children and adolescents are more susceptible to depression due to social networking and the internet than women and men. While women are more susceptible to depression than men. However, it does not explain what makes certain groups of age such as adolescents have more risk of depression than adults.

Depression caused by social networking is influenced by the use of social networking itself. The way a person treats social networking as part of his life affects whether he or she will easily experience depression caused by social networking. The more serious a person treats social networking, the more serious the impact it will have on the person's emotions. It is considering social networking as too important to the person, so it can make a person vulnerable to depression due to social networking.

Another reason why social networking can cause depression is because many people just pretend to be happy when creating their identity and self-image in cyberspace. Very few people actually show their lives as they are on social networks. This kind of thing can also cause depression to others because they think life is not as good as you. 
Unconsciously, the pretense that exists in social networking causes many people become depressed by comparing to another's life.

One thing that experts suggest is the fair use of social networks. Do not make social network as your life, because your life is not in the virtual world and it is not reflected in what you show on social networks, so never compare your life to other.

In addition, experts also advise to not compare themselves with others because this can lead to great depression. Direct communication is more important than just relying on social networking. Do not make communication through social networking as your personal needs.

For users of social networking, depression due to social networking seems trivial. But you never know when depression can really affect mental health and even trigger many people to take fatal action just because the impact of social networking.

When viewed from the positive impact, the existence of social media is actually very useful as a means of communication, because this social media can be used to promote or introduce our business, it also can convey ideas and someone's ideas can be read by others in order to add knowledge and add repertoire of scholarship. With the development of social media from time to time, it should be relevant with government monitor about the development of social media in Indonesia and block negative content so as not to be abused. We should wise in using social media as a means of communication and updating information. 
Vol. 1, No. 1, Januari 2020: h. 106-130. DOI: 10.35672/jnus.v1i1.106-130 Website: http://jnus.lakpesdamsalatiga.or.id/index.php/jnus/index

\section{CONCLUSION}

This article discusses the impacts of using social media on the development of da'wah and the behavior of Indonesians. This chapter uses observational media and random survey results of several samples. The research findings show that the use of social media to the development of da'wah is very good and efficient in terms of time, cost and energy. Currently there are many outstanding applications for delivering da'wah. In addition to the development of da'wah, social media also brings tremendous impact on the behavior of Indonesian society. This is proven by the fast life changing which is, modern, practical and efficient. It is warmly welcomed by the Indonesian people for technological progress.

\section{BIBLYOGRAPHY}

Asmiati, Rita. 2015. Benefits of Social Networking as a Da'wah Media. Retrieved fromThe Heat Is Online website : http://rithasmiati.blogspot.co.id/2015/09/manfaat-jejaringsosial-sebagai-media.html. // access date $2^{\text {nd }}$ November 2017.

Ayun, P. Q. (2015). The phenomenon of adolescents using social media in forming identity. Journal Komunikasi, Vol. 3(2), 1-16.

Banyai, F., Zsila, A., Kiraly, O., Maraz, A., Elekes, Z., Griffiths, M. D., Demetrovics, Z. (2017). Problematic social media use: results from a large-scale nationally representative adolescent sample. Jurnal Pone, 12(1), 1-13. doi:10.1371/journal.pone.016983. 
The Influence of Social Media for .... (Avin Wimar Budyastomo)

Bohjalian, E. (2017). The self-presentation of popular fitspiration experts on instagram. Journal of Undergraduate Research in Communications, vol. 8(1), 23-34.

Boyd, M. D., \& Ellison, B. N. (2007). Social network sites :definition, history, and scholarship. Journal of Computer-Mediated Communication, 13(1).

Choi, Y. H., \& Bazarova, N. N. (2014). Self-disclosure characteristics and motivation in social media: extending the functional model to multiple social network sites. International Communication Association, 41(4), 480-500. doi:doi:10.1111/hcre.12053.

Dewani, Wien. 2015. Influence of Social Media for students “.Retrieved from The Heat Is Online website : https://wiendewani.wordpress.com/2015/06/09/karya-ilmiahpengaruh-media-sosial-bagi-pelajar/ access date $1^{\text {st }}$ November 2017.

Habib, Zamris. 2014. The Role of Social Media in the Development of Preaching. Retrieved fromThe Heat Is Online website : http://www.zamrishabib.web.id/2014/12/peranan-mediasosial-dalam-pengembangan.html. $/ /$ access date $2^{\text {nd }}$ November 2017.

Juditha, Christiany. 2011. The Relationship Between The Use Of Facebook And Teenegers' Behavior In Makassar. Journal Vol. 13 (1) 2011. Central for the Study and Development of Communication and Information Technology. Makasar.

Kurniawan, Ari. 2013. Effect of Social Networking Sites on the Behavior of Young Generation. Guidance and Counseling Study 
JNUS:Journal of Nahdlatul Ulama Studies

Vol. 1, No. 1, Januari 2020: h. 106-130. DOI: 10.35672/jnus.v1i1.106-130

Website: http://jnus.lakpesdamsalatiga.or.id/index.php/jnus/index

Program. Faculty of Teacher Training and Education. PGRI University of Yogyakarta.

Pardianto.2013. Upholding Da'wah Through with a New Media. Journal Vol.3 (1) 2013. Institut Agama Islam Negeri (IAIN), Ambon.

Ramadhani, B, Zukhria. 2013. Positive \& Negative Impact of Social Networking Sites seen from Social, Cultural and Legal Aspects. Retrieved fromThe Heat Is Online website http://dampakpositifdannegatifsitus.blogspot.co.id/. // access date $1^{\text {st }}$ November 2017. 